Board of Governors of the Federal Reserve System

International Finance Discussion Papers

Number 668

June 2000

\title{
HOW CONSISTENT ARE CREDIT RATINGS? A GEOGRAPHIC AND SECTORAL ANALYSIS OF DEFAULT RISK
}

\author{
John Ammer and Frank Packer*
}

NOTE: International Finance Discussion Papers are preliminary materials circulated to stimulate discussion and critical comment. References to International Finance Discussion Papers (other than an acknowledgment that the writer has had access to unpublished material) should be cleared with the author or authors. Recent IFDPs are available on the Web at www.bog.frb.fed.us. 


\title{
HOW CONSISTENT ARE CREDIT RATINGS? A GEOGRAPHIC AND SECTORAL ANALYSIS OF DEFAULT RISK
}

\author{
John Ammer and Frank Packer*
}

\begin{abstract}
We examine differences in default rates by sector and obligor domicile. We find evidence that credit ratings have been imperfectly calibrated across issuer sectors in the past. Controlling for year of issue and rating, default rates appear to be higher for U.S. financial firms than U.S. industrial firms. Sectoral differences in recovery rates do not offset the higher default rates. By contrast, we do not find significant differences in default rates between U.S. and foreign firms.
\end{abstract}

Keywords: bonds, rating agencies, capital requirements, Basel Committee on Banking Supervision

* Ammer is an Economist in the International Finance Division at the Board of Governors of the Federal Reserve System and can be contacted at John.Ammer@frb.gov. Packer is a Director at Salomon Smith Barney in Tokyo and can be contacted at Frank.Packer@nssmb.com. The analysis was performed while Packer was a staff economist at the Federal Reserve Bank of New York. The views expressed herein are those of the authors, and do not necessarily reflect those of Salomon Smith Barney, the Federal Reserve Board, the Federal Reserve Bank of New York, or any other employees of the Federal Reserve System. We would like to thank Paul Kim for diligent research assistance and workshop participants at the Federal Reserve Board and members of the Basel Committee Working Group on Credit Ratings for helpful comments. 
1. Introduction. Credit rating agencies assign bond ratings using similar lettergrade scales for a wide variety of issuers - sovereigns, municipal governments, industrial firms, and financial institutions located in many countries. At the same time, the determinants of default risk may differ across industry sector and geographic location; maintaining consistency across sectors is hardly a trivial task.

The importance of sectoral comparisons of credit risk has been heightened by a proposed change in bank capital regulation. The Basel Committee on Banking Supervision [1999] has outlined possible regulatory changes that would entail greater reliance on external ratings to determine the risk weighting of banking book assets. In particular, the risk weighting would depend on both the credit rating and the sector (i.e., sovereigns, banks, or corporates). Sovereign credits would have reduced risk weightings relative to banks when rated $\mathrm{A}$ or higher and relative to corporates when rated $\mathrm{BBB}$ or higher. Bank credits would have lower risk weightings than corporate credits at A and BBB ratings. ${ }^{1}$ At other ratings, the charges would be identical across sectors. Different weights for different sectors may be appropriate if ratings reflect different levels of expected loss.

This paper examines the extent to which default rates and recoveries in the event of default differ between banks and non-financial issuers. We also investigate whether obligor domicile has affected the association of credit ratings with default probabilities and recoveries. Most of the major credit rating agencies are headquartered in the United States. To the extent that the Basel Committee proposal expands the role of U.S. ratings of foreign entities, then the degree to which these ratings are consistent across obligor domicile is of greater interest. International differences in accounting and legal systems, 
business practices, and the role of government in the economy may make it difficult to compare the default risk of bond issuers domiciled in different countries.

Our empirical results suggest that credit ratings have not always been consistent across issuer sectors. In particular, U.S. banks experienced significantly more defaults than U.S. industrial firms did over the period 1983-1998, taking the year and credit rating as given. These results are at odds with the proposal that, for some rating levels, bank obligations carry a lower capital requirement than an otherwise identical liability of an industrial firm. Nevertheless, it is worth noting that our sample period may be somewhat atypical for the U.S. in that it included an interval in which an unusually large number of depository institutions failed.

On the other hand, credit ratings appear to have been calibrated more successfully across U.S. and foreign issuers. Apparent geographical discrepancies in default rates are no longer significant once we simultaneously control for the credit rating and time period.

2. The Literature. The literature on sectoral differences in the measurement of credit risk is fairly limited. Few papers address default rates directly, and we know of no previous work that undertakes a systematic statistical analysis of sectoral differences in default rates.

Most existing papers on sectoral differences employ less direct measures of credit risk than actual default experience, often finding evidence that banks are relatively risky. For example, Donald Morgan [1998] finds that rating agency disagreements for a given issuer (so-called "split ratings") are more frequent in banking than in other sectors, suggesting that banks are relatively opaque for the purpose of credit risk measurement. Similarly, Jackson and Perraudin [1999] document a tendency for yield spreads to be 
higher on bank debentures throughout the 1990s than spreads on comparably rated corporate bonds, suggesting that bond investors perceive banks as being riskier. In addition, Altman and Kishore [1996] report lower recovery rates for U.S. financial firm issuers that have defaulted than for U.S. industrial bonds. Finally, Nickell, Perraudin, and Varotto [1998] focus on rating "transitions" (also known as rating "migrations"), and conclude that banks tend to have less stable ratings than industrials. A table in their paper also contains an implicit comparison of bank and industrial default rates, but with mixed results and without statistical significance.

With regard to obligor domicile, Japan Center for International Finance [1999] finds that Moody's ratings of Japanese firms may be relatively tough, since fewer defaults have been observed over time in Japan than would have been predicted by Moody's ratings in conjunction with U.S. corporate default rates. A few other papers offer indirect evidence of "home bias" in credit ratings. An examination of split ratings by Beattie and Searle [1992] suggests that agencies judge issuers from their own country more leniently. However, Cantor and Packer [1994] find that, for ratings of international banks, observed differences between home and foreign ratings reflected principally differences in the scales of individual ratings agencies, rather than home-country bias. Nevertheless, Nickell, Perraudin, and Varotto [1998] find that higher rated Japanese firms are more likely to be downgraded by Moody's and that Japanese firms with low ratings were less likely to be upgraded.

3. Descriptive Statistics: Default Rates by Sector. Table 1 reports the one-year default rates between 1983 and 1998 by initial rating and sector of issuer, according to the Moody's database. The same underlying database is used in Moody's annual default 
studies [e.g., Moody's Investors Service, 1999b]. The default rates are calculated using estimates of mid-period denominators, constructed by subtracting half of the number of ratings withdrawn (over the whole period) from the number of rated issuers at the beginning of the period. The implicit assumption in this construction is that ratings withdrawals are distributed evenly through the period. The mid-period denominator produces a measure of the default rate that approximates the average continuous "hazard rate" of default over the period. Carty [1997] notes that rating withdrawals generally are not adverse credit events, so that removing withdrawn ratings from the denominator does not introduce a sample selection bias into default rates.

Default rates are measured across seven sectors-U.S. banks, other U.S. financial firms, U.S. non-financial firms, foreign banks, other foreign financial firms, foreign nonfinancial firms, and sovereigns. In terms of overall default rates, the default rate for U.S. banks of $1.65 \%$ is somewhat lower than the $1.93 \%$ we report for U.S. non-financial firms. Both are well above the default rate of $0.54 \%$ for foreign non-financial firms, which in turn is higher than the $0.08 \%$ default rate for foreign banks. Based on these numbers alone, it appears that U.S. firms are riskier than foreign firms are, and foreign banks are particularly safe. Only one sovereign defaulted on a foreign-currency bond rated by Moody's during our sample period, a late payment on a Eurobond by Pakistan in 1998.

However, overall sectoral default rates offer an incomplete picture of sectoral differences in the correspondence of ratings to default, since the underlying ratings composition of each sectoral pool of borrowers is likely to differ. For instance, if the average ratings of U.S. banks were much higher for U.S. non-financial firms, the similar default rates would imply that ratings were relatively lenient for banks. Or, if the average 
ratings of foreign firms were much higher than for U.S. firms, the observed difference in the default rates may result purely from this difference of ratings composition.

In Table 2, we control for the ratings composition and report the one-year default rates for U.S. banks vs. U.S. non-financial firms at Moody's investment-grade ratings (Baa3 and higher), as well as for three groupings of Moody's speculative-grade ratings. Same-year defaults by investment-grade issuers are extremely rare, as is implied by the $0.0 \%$ default rates in this row of the table.

At lower rating levels, however, there are apparent sectoral differences. U.S. banks rated Ba1-Ba3 showed a slightly higher propensity to default than U.S. nonfinancial firms (2.0\% vs. $1.5 \%)$, and the default rates are distinctly higher for banks in the B1-B3 range (14.0\% vs. $6.7 \%)$ and the Caa1-C range $(56.4 \%$ vs. $16.6 \%)$ as well. In the geographical comparison in the next two columns, U.S. firms rated Ba show somewhat higher default rates, whether rated $\mathrm{Ba}(1.5 \%$ vs. $0.9 \%)$, Ba (7.0\% vs. $2.4 \%)$, or lower (19.0\% vs. $15.2 \%)$. These figures suggest that credit ratings were more conservative for U.S. industrials than for U.S. banks during our sample period and more conservative for foreign firms than for U.S. firms. ${ }^{2}$

4. Probit Analysis. Of course, the distinctions that were noted in Tables 2 could be a reflection of factors other than genuine sectoral differences. Differences over time in the frequency of sectoral ratings, combined with different default patterns across time, could account for the differences. For instance, a much greater percentage of ratings, particularly at the lower rating levels, have been assigned to foreign borrowers since the mid-1990s than previously. But to the extent that recent years have been characterized by surprisingly good economic conditions and correspondingly low default rates 
worldwide, then the lower default rates observed for foreign borrowers at given ratings would be expected, independent of any putative "home bias" effect in ratings.

Accordingly, we proceed with multivariate probit models, estimated over 37,300 "issuer-years", in which the dependent variable is the probability that the issuer defaulted that year. Our estimation period begins in 1983, when Moody's began assigning alphanumeric ratings (i.e., Baa3, Ba1, etc., rather than letter grades only). The key explanatory variables are binary indicator variables for four broad issuer classes: U.S. non-financial firms, U.S. banks, other U.S. financial firms, and foreign firms. (Sovereign issuers were excluded from the sample and foreign firms were lumped into a single category, in order to insure that each group used in the estimation had enough low-rated issuer-years to make reliable inferences about default risk.) We also include dummy variables for credit ratings, to allow for predicted variation in credit risk, and time dummies for each year, in order to control for temporal variation in default risk. Because all of the explanatory variables are binary, the probit specification can be written as:

$$
P(j) \equiv \operatorname{Pr}\left(D_{j}=1\right)=\Phi\left(\beta^{0}+\beta^{T_{j}}+\beta^{R_{j}}+\beta^{S_{j}}\right) \quad j=1, \ldots, N
$$

In (1), $D_{j}$ equals one when the $j$-th issuer-year corresponds to an observation when the issuer defaulted that year, $\Phi$ denotes the cumulative normal density function, and $\beta^{0}$ is an intercept coefficient. In addition, $\mathrm{T}_{\mathrm{j}}$ refers to the calendar cohort to which the $\mathrm{j}$-th issueryear belongs, $R_{j}$ is the beginning-of-year alphanumeric rating level for $j$, and $S_{j}$ denotes j's sector. 
Because near-term defaults by highly rated issuers are very rare, rating level dummies are included only for ratings Baa1 and lower. Caa1 ratings and lower are treated as a single group. Time dummies are included for the fifteen cohorts from January 1983 to January 1997, with the January 1998 dummy omitted, in order to avoid introducing a singularity into the matrix of explanatory variables. Similarly, we always omit the sector dummy for U.S. non-financial firms. Accordingly, our estimated intercept term will correspond to the probability of default for a high-rated (above Baa1) U.S. non-financial firm in 1998.

We estimate the parameters $(\beta)$ by numerically maximizing the model's likelihood function. Estimated coefficients are reported for two variations of the model in Table 3. The first includes a single sector dummy for foreign firms to emphasize the geographical comparison, while the second also includes dummy variables for U.S. banks and other U.S. financial firms, to enable broad industry comparisons.

The positive estimated coefficient (0.04) for foreign firms for our first model implies that overseas borrowers are subject to higher default risk, once we control for time and rating effects, although with a standard error of 0.10 , the estimate is not statistically distinguishable from zero. The sign of the coefficient stands in stark contrast to the default rates reported in Table 2, where U.S. firms appeared to be substantially riskier, when only ratings were taken into account. Our results imply that the lower default rates for Japanese firms reported by Japan Center for International Finance [1999] does not stem from a "home bias" against foreign issuers, in general, on the part of U.S. rating agencies. 
The parameter estimates for the time dummies, which are almost uniformly higher from 1983 to 1991 than for later years, help explain how the "home bias" implication of Table 2 has been overturned. More than 78 percent of the foreign firm issuer-years in our sample came from the last 7 years of our sample (1992-1998), when default rates were lower, compared to 48 percent of the U.S. firm issuer-years. In other words, foreign default rates have been lower because most of the foreign firm rating experience has occurred during a relatively benign period for default risk.

The results in the last column, however, show that the higher frequency of U.S. bank defaulters at a given rating (compared to U.S. non-financial firms, as documented in Table 2) is both robust to time effects and statistically significant. This finding supports less direct evidence found in other papers that, at least ex post, default risk has been higher for bank obligations. The sector coefficient for banks is 0.25 . Incidentally, this is roughly the amount by which the estimated rating coefficients increase as one moves a single rating notch lower in credit quality, for example from Baa3 (with an estimated coefficient of 1.07) to Ba1 (with an estimated coefficient of 1.28). In fact the average incremental increase in the ratings coefficients from Baa1 to B3 is 0.29. This comparison suggests that, at least ex post, U.S. banks have been over-rated by about one rating notch, relative to U.S. non-financial firms. We also estimate a positive coefficient for other U.S. financial firms, but it is smaller in magnitude and it is not statistically significant with 95 percent confidence, with a t-statistic of about 1.3 .

Because the probit representation is based on a non-linear multivariate function, the impact of an individual parameter estimate on the probability of default is difficult to interpret out of context. To facilitate interpretation of the results, Table 4 reports average 
fitted default rates over each sector, based on the estimated probit coefficients. These are computed over the whole sample of $\mathrm{N}$ issuer-years, by holding the rating and year cohort fixed for each observation, but allowing the sector to vary, as follows (where $S_{k}$ designates the sector):

$$
\bar{P}\left(S_{k}\right) \equiv \frac{1}{N} \sum_{j=1}^{N} \Phi\left(\beta^{0}+\beta^{T_{j}}+\beta^{R_{j}}+\beta^{S_{k}}\right)
$$

In $(2)$, coefficients $(\beta)$ for sectors for which the dummy variable has been omitted from the model estimation are implicitly equal to zero.

Working from the estimated coefficients of the restricted model, in which the three classes of U.S. firms are treated as a single group, the average fitted one-year default probability is just a hair higher (1.51 percent versus 1.42 percent) for foreign firms than for U.S. firms. For the unrestricted model, however, the average fitted default rate is strikingly higher (2.14 percent versus 1.37 percent) for U.S. banks than for U.S. non-financial firms. Other U.S. financial firms also show a higher implicit default rate, though it should be kept in mind that the difference is based on a sector coefficient that is too imprecise to be statistically significant.

While the probit results are indicative of statistical significance, it is important to be aware that the default rate discrepancies with regard to U.S. bank and U.S. nonfinancial firm result principally from one historical episode - the thrift crisis of the late 1980s and early 1990s. Table 5 indicates that 21 of the 33 defaults for banks in the whole period 1983-1998 were of U.S. thrifts in the period 1989-1991. More than 40 percent of 
the 51 thrifts that had Moody's ratings defaulted during that 3-year period. In retrospect, Moody's greatly overestimated the ability of lower-quality thrifts to service their bond obligations during the years 1989-1991. Nevertheless, to the extent that there have been dramatic changes in the U.S. bank regulatory regime, and the methodology for rating banks has been adjusted to account for them, bank ratings will not necessarily be more lenient—i.e., associated with higher default rates at a given credit rating — going forward.

5. Recovery Rates. Since expected losses are a function of both the expected probability of default and the expected severity of loss given default, sectoral differences in the probability of default at given ratings do not necessarily imply sectoral differences in expected losses. If default rates were counter-balanced by differences in recovery rates, then the expected losses could be the same across sectors. And in contrast to Standard and Poor's ratings, which are intended to rank the relative likelihood of corporate default only, Moody's explicitly indicates that it includes considerations of recovery in its corporate ratings.

To explore the degree to which recoveries differ by sector, we again turn to the Moody's database. Here the recovery rate is measured as the secondary market price of a bond 30 days after default. We examine recoveries on the bonds of 492 issuers that were rated by Moody's and defaulted between 1983 and 1998. In cases in which prices are available for multiple bonds of the same firm, we use an average, weighted by face value outstanding, of recoveries for that firm.

In Table 6, we report the recovery rate on the defaulted corporate bonds, broken out in the first two rows by U.S. bank versus U.S. non-financial firms, and then in the next two rows, by U.S. versus foreign firms. (The absence of a separate category of U.S. 
non-bank financial firms explains why the first two rows do not quite add up to the third.)

The U.S. bank recoveries are starkly lower, with an average recovery of 22 percent versus about 41.7 percent for non-financial firms. The statistic resulting from the t-test on the differences is 4.2 , indicating statistical significance beyond the 95 percent confidence level. ${ }^{3}$ By contrast, the average recoveries for the bonds of 22 rated foreign firms that defaulted is 42.5 percent, which does not differ significantly from 40.4 percent figure for the sample of 470 rated U.S. firms.

Thus, differences in default rates between U.S. banks and U.S. non-financials were not counterbalanced by the differences in recoveries on those defaults. In fact, the recoveries tended to be much lower for U.S. banks than those for U.S. non-financial firms. On the other hand, keeping in mind that neither result is large in magnitude nor statistically significant, the slightly lower default rates for U.S. relative to non-US firms may have been accompanied by somewhat lower average recovery rates.

6. Conclusions. In summary, we find limited evidence that credit ratings have been imperfectly calibrated across issuer sectors in the past. In particular, for a given credit rating, default rates seem to be higher for U.S. financial firms than for U.S. corporates, but similar for U.S. firms relative to those domiciled in other countries. Sectoral differences in downgrade rates and recovery rates do not offset the higher default rate for U.S. banks, in terms of overall credit risk. However, particularly if bank supervision has become more effective or bank rating methodologies have been adjusted, one would not necessarily expect U.S. bank default rates to be higher going forward.

In addition, a few recent reports indicate that rating agencies are paying increasing attention to sectoral comparisons [e.g., Standard and Poor's, 1999]. According 
to Moody's [1999a], U.S. bond markets were sufficiently segmented in the past that investors would not necessarily have expected ratings to be calibrated across broad sectors such as utilities, corporates, municipals, and structured finance. Going forward, however, Moody's intends to increase efforts to harmonize its ratings across sectors.

One limitation of our analysis is that the rating agencies do not provide historical data on their ratings in all sectors, most notably in municipal and structured finance. The municipal finance area is one in which ratings are reputedly tougher and thus associated with lower default probabilities [e.g., Moody's Investors Service, 1999a]. However, the data are simply not available to investigate the performance of ratings in those industry sectors relative to other sectors.

Disclosure of ratings histories may be a signal of the stability and dependability of those histories. In that case, we would expect any ratings inconsistencies observed across sectors and across countries in a rating agency's public default database to be a lower bound of the unobserved inconsistencies that may exist more generally in the rating industry. 
Endnotes:

${ }^{1}$ We do not address an alternative proposal for bank obligations in which the risk weighting is based on the credit rating of the sovereign in which the bank is domiciled, rather than the rating of the bank itself.

${ }^{2}$ Higher default rates are also observed for U.S. banks relative to U.S. non-financial firms conditional on Standard and Poor's letter-only ratings for the period 1981-1998.

${ }^{3}$ We get similar results when we only use recovery prices for subordinated bonds, which are available for 319 of the 492 firms. Altman and Kishore [1996] also report lower recovery rates for U.S. financial firms than for U.S. industrial firms, although the magnitude of the difference they find is somewhat smaller. 


\section{References}

Altman, Edward and Vellore Kishore [1996]. "Almost Everything You Always Wanted to Know About Recoveries on Defaulted Bonds," Financial Analysts Journal, (November/December), 57-63.

Basel Committee on Banking Supervision [1999]. "Capital Adequacy Framework," (June).

Beattie, Vivien and Susan Searle [1992]. "Credit Rating Agencies: The Relationship between Rater Agreement and Issuer/Rater Characteristics.” Journal of International Securities Markets, (Winter), 371-375.

Cantor, Richard and Frank Packer [1994]. "The Credit Ratings Industry," Federal Reserve Bank of New York Quarterly Review, (Summer/Fall), 1-26.

Carty, Lea [1997]. "Moody's Rating Migration and Credit Quality Correlation, 19201996," Moody’s Special Report (July).

Jackson, Patricia and William Perraudin [1999]. "The Nature of Credit Risk: The Effect of Maturity, Type of Obligor, and Country of Domicile," Financial Stability Review, (November), 128-140.

Japan Center for International Finance [1999]. "Characteristics and Appraisal of Major Rating Companies -- Focusing on Ratings in Japan and Asia,” (April).

Moody's Investors Service [1999a]. "The Evolving Meaning of Moody's Bond Ratings." (August).

Moody's Investors Service [1999b]. "Historical Default Rates of Corporate Bond Issuers," (January).

Morgan, Don [1998]. “Judging the Risks of Banks: What Makes Banks Opaque?" Federal Reserve Bank of New York Working Paper, (March).

Nickell, Pamela, William Perraudin, and Simone Varotto [1998]. "Stability of Transition Matrices," (December), Bank of England working paper.

Standard and Poor's [1999]. "Sovereign versus Corporate Ratings Stability," Credit Week, (September 29), 9-13. 


\begin{tabular}{|c|c|c|c|}
\hline \multicolumn{4}{|c|}{$\begin{array}{l}\text { One-Year Default Rates by Type of Issuer } \\
\qquad(1983-1998)\end{array}$} \\
\hline Type of Issuer & Default Rate & $\begin{array}{l}\text { Number of } \\
\text { Defaults }\end{array}$ & $\begin{array}{c}\text { Effective } \\
\text { Denominator } \\
\text { (Issuer-Years) }\end{array}$ \\
\hline U.S. Banks & $1.65 \%$ & 33 & 1995 \\
\hline Other U.S. Financial Firms & $0.84 \%$ & 33 & 3950 \\
\hline U.S. Non-Financial Firms & $1.93 \%$ & 440 & 22757 \\
\hline Foreign Banks & $0.08 \%$ & 2 & 2387 \\
\hline Other Foreign Financial Firms & $0.61 \%$ & 15 & 2473 \\
\hline Foreign Non-Financial Firms & $0.54 \%$ & 20 & 3738 \\
\hline Sovereigns & $0.17 \%$ & 1 & 574 \\
\hline Total & $1.44 \%$ & 544 & 37874 \\
\hline
\end{tabular}




\begin{tabular}{|ccccc|}
\hline \multicolumn{5}{c}{$\begin{array}{c}\text { Table 2 } \\
\text { One-Year Default Rates by Initial Credit Rating } \\
\text { (1983-1998) }\end{array}$} \\
\hline Credit Ratings & U.S. Banks & $\begin{array}{c}\text { U.S. Non- } \\
\text { Financials }\end{array}$ & All U.S. Firms & Foreign Firms \\
\hline Aaa to Baa3 & $0.0 \%$ & $0.0 \%$ & $0.0 \%$ & $0.0 \%$ \\
\hline Ba1 to Ba3 & $2.0 \%$ & $1.5 \%$ & $1.5 \%$ & $0.9 \%$ \\
B1 to B3 & $14.0 \%$ & $6.7 \%$ & $7.0 \%$ & $2.4 \%$ \\
Caa1 to C & $56.4 \%$ & $16.6 \%$ & $19.0 \%$ & $15.2 \%$ \\
\hline
\end{tabular}




\begin{tabular}{|c|c|c|}
\hline \multicolumn{3}{|c|}{$\begin{array}{c}\text { Probit Model Estimates for } \\
\text { One-Year Default Rates, 1983-1998 }\end{array}$} \\
\hline Intercept & $-4.08(0.21)$ & $-4.12(0.20)$ \\
\hline \multicolumn{3}{|l|}{ Dummy variables for: } \\
\hline 1983 Cohort & $0.21(0.16)$ & $0.21(0.16)$ \\
\hline 1984 Cohort & $0.32(0.15)$ & $0.32(0.15)$ \\
\hline 1985 Cohort & $0.30(0.14)$ & $0.29(0.14)$ \\
\hline 1986 Cohort & $0.57(0.11)$ & $0.57(0.11)$ \\
\hline 1987 Cohort & $0.36(0.11)$ & $0.36(0.11)$ \\
\hline 1988 Cohort & $0.23(0.11)$ & $0.21(0.11)$ \\
\hline 1989 Cohort & $0.57(0.10)$ & $0.56(0.10)$ \\
\hline 1990 Cohort & $0.74(0.10)$ & $0.72(0.09)$ \\
\hline 1991 Cohort & $0.71(0.10)$ & $0.69(0.10)$ \\
\hline 1992 Cohort & $0.22(0.12)$ & $0.20(0.12)$ \\
\hline 1993 Cohort & $0.14(0.13)$ & $0.13(0.12)$ \\
\hline 1994 Cohort & $-0.19(0.13)$ & $-0.20(0.13)$ \\
\hline 1995 Cohort & $0.03(0.10)$ & $0.03(0.10)$ \\
\hline 1996 Cohort & $-0.39(0.13)$ & $-0.39(0.13)$ \\
\hline 1997 Cohort & $-0.28(0.12)$ & $-0.28(0.12)$ \\
\hline Baa1 Rating & $0.40(0.35)$ & $0.40(0.35)$ \\
\hline Baa2 Rating & $0.63(0.28)$ & $0.64(0.28)$ \\
\hline Baa3 Rating & $1.06(0.24)$ & $1.07(0.24)$ \\
\hline Ba1 Rating & $1.28(0.22)$ & $1.28(0.21)$ \\
\hline Ba2 Rating & $1.25(0.22)$ & $1.27(0.22)$ \\
\hline Ba3 Rating & $1.80(0.20)$ & $1.83(0.20)$ \\
\hline B1 Rating & $2.02(0.20)$ & $2.05(0.20)$ \\
\hline B2 Rating & $2.37(0.20)$ & $2.40(0.20)$ \\
\hline B3 Rating & $2.70(0.20)$ & $2.73(0.20)$ \\
\hline Caa-C Rating & $3.14(0.21)$ & $3.16(0.20)$ \\
\hline Foreign Firms & $0.04(0.10)$ & $0.05(0.09)$ \\
\hline U.S. Banks & & $0.25(0.11)$ \\
\hline Other U.S. Financial Firms & & $0.12(0.09)$ \\
\hline
\end{tabular}

Notes: Standard errors are in parentheses. Coefficients that are non-zero with 95 percent confidence are shown in bold face. 


\begin{tabular}{|c|c|c|}
\hline \multicolumn{3}{|c|}{$\begin{array}{l}\text { Average Fitted One-Year Default Rates } \\
\text { from Probit Model Estimates }\end{array}$} \\
\hline & 1998 & \\
\hline & $\begin{array}{l}\text { Restricted } \\
\text { model }\end{array}$ & $\begin{array}{c}\text { Unrestricted } \\
\text { model }\end{array}$ \\
\hline U.S. Non-Financial Firms & & $1.37 \%$ \\
\hline U.S. Banks & & $2.14 \%$ \\
\hline Other U.S. Financial Firms & & $1.71 \%$ \\
\hline All U.S. Firms & $1.42 \%$ & \\
\hline All Foreign Firms & $1.51 \%$ & $1.50 \%$ \\
\hline
\end{tabular}

Note: Average fitted default rates are computed over the whole sample of issuer-years, by keeping the rating and year cohort fixed for each observation, but allowing the sector to vary. 


\begin{tabular}{|c|c|c|c|}
\hline \multicolumn{4}{|c|}{ Bond Defaults by U.S. Thrifts (1989-1991) } \\
\hline Credit Ratings & $\begin{array}{l}\text { Number of } \\
\text { Defaults }\end{array}$ & $\begin{array}{c}\text { Effective } \\
\text { Denominator } \\
\text { (Issuer-Years) }\end{array}$ & $\begin{array}{c}\text { One-Year Default } \\
\text { Rate }\end{array}$ \\
\hline Aaa to Baa3 & 0 & 39 & $0.0 \%$ \\
\hline $\mathrm{Ba} 1$ to $\mathrm{Ba} 3$ & 2 & 39 & $5.1 \%$ \\
\hline $\mathrm{B} 1$ to $\mathrm{B} 3$ & 13 & 42 & $31.0 \%$ \\
\hline Caa1 to C & 6 & 10 & $60.0 \%$ \\
\hline Total & 21 & 130 & $16.2 \%$ \\
\hline
\end{tabular}




\begin{tabular}{|c|c|c|c|}
\hline \multicolumn{4}{|c|}{$\begin{array}{l}\text { Recovery Rates on Defaulted Corporate Bonds } \\
\qquad(1983-1998)\end{array}$} \\
\hline Type of Issuer & Number of Cases & Average Recovery & Difference \\
\hline U.S. Bank & 26 & $22.0 \%$ & \\
\hline U.S. Non-Financial & 423 & $41.7 \%$ & $\begin{array}{c}19.7 \\
(4.2)\end{array}$ \\
\hline U.S. Firm & 470 & $40.4 \%$ & \\
\hline Foreign Firm & 22 & $42.5 \%$ & $\begin{array}{c}2.0 \\
(0.7)\end{array}$ \\
\hline Total & 492 & $40.5 \%$ & \\
\hline
\end{tabular}

Notes: T-statistics for differences are in parentheses. Recovery rate is measured as the secondary market price of a bond 30 days after default, as a percent of face value. 